\title{
Resort hotels in transition: Antalya, Turkey
}

\author{
S. Doganer \\ The University of Texas at San Antonio, College of Architecture, USA
}

\begin{abstract}
This study aims to explore the economic, political, social, cultural, organizational and time-dependent changes in tourism, and the impact of such changes on resort hotel design, and to discuss renovation of resort hotels in transition, using as a case study the city of Antalya, Turkey. This research hopes to assist in developing a new, more conscious approach to the design process of these buildings. In the second half of the $20^{\text {th }}$ century, mass tourism began to spread; the profile of tourists, as well as their expectations and demands, have changed. Consumption now dominates the tourism market. Moreover, there have been significant economic, political, social, cultural and organizational changes that have affected the tourism industry. In order to remain competitive, resort hotels have also changed, renovated and evolved, in an effort to meet consumers and tour operators' expanding demands, to accommodate more stringent international environmental standards, to keep up with recent developments in management, technology and design, to increase their market share and ensure repeat business, and to provide the 'new', the 'popular' and the 'different' that so many tourists have come to expect. Today, it is apparent that the demands of consumers who frequent resort hotels have changed; it is now insufficient simply to provide accommodations. Consumers expect entertainment, adventure and seemingly-limitless facilities. In this intense rivalry, it is necessary to be distinctive, to present a 'new' image, as well as to offer various recreational facilities, in order to survive in the market. Likewise, other elements once considered fashionable, may no longer be relevant to the modern traveler, since their tastes tend to change rapidly. However, those resorts focusing on diversity in their facilities, resorts that offer performances, shows and activities geared toward fulfilling guests' demands for 'experiencing the different' without conceding architectural quality and uniqueness, will be more successful in the long term. As a consequence of these developments in the tourism industry, the number of resort hotels in Antalya has increased rapidly
\end{abstract}


and the activities they offer have become more diverse. By analyzing the renovations made to these resort hotels, this research evaluates the reasons for and results of these changes, explores the spaces created by these transformations, and develops proposals for building a more conscious approach to the overall design process.

Keywords: architecture, design, resort hotel, change, transition, renovation, sustainability.

\section{Introduction}

By the second half of the $20^{\text {th }}$ century, the global tourism industry began to change dramatically. Rapid developments in communication, transportation and technology caused significant social, economic and political shifts in the world, and the tourism industry responded by adjusting its focus to a consumptionbased form of mass tourism. These days, 'tourism centers' have become 'consumer centers' where visual images are rapidly consumed and tourists are encouraged to experience numerous different activities and games.

This study aims to explore the economic, political, social, cultural, organizational and time-dependent changes in tourism, and the impact of such changes on resort hotel design. Constant change is inevitable for resort hotels if such hotels hope to meet consumer and tour operators' expanding demands, to adhere to international enviromental standards, to keep up with recent developments in management, technology and design, to increase their market share and ensure repeat business, and to provide the 'new', the 'popular' and the 'different' that tourists have come to expect, and resort hotels need to offer in order to survive. It is within this context that the changes and renovations made to resort hotels will be explored and discussed, in an effort to analyze the changing tendencies and design principles, the new functional and spatial necessities, and the ever-evolving design processes.

The Mediterranean resort area of Antalya, Turkey has been chosen as a focused study area for this research. Tourism in Antalya began to develop rapidly by the beginning of 1980s. The newly elected Liberal Government took action to make tourism a potential new industry by using its legislation power to pass less stringent environmental regulations, offer low-interest loans, and encourage both domestic and foreign investors. With the help of the post-Cold War Era and the convenient geographical location of Turkey, a new strategy evolved, and the very notion of investing in the tourism industry became a trend in Turkey. By the late 1990s and early 2000s, this trend made an additional leap forward. Rapid developments in communication, transportation and technology changed global supply and demand.

The impacts of these changes to the tourism environment and resulting resort hotel design will be analyzed here through a case study of twelve resort hotels that were renovated in Antalya between 2001 and 2005. Subsequent to the case study, this research analyzes whether it is possible to assess the ever-changing resort hotels within conventional design constraints. Finally, this research will discuss the architect's role in the design process and the need for a new typology 
for resort hotels as they endeavor to host an endless variety of functions, set up temporary experiences, and accommodate the frequent changes to trends in consumption.

\section{Changes in tourism and resort hotel design}

Change is an unavoidable fact of today's design cycle. The only thing that does not change is change itself. Changes made to the design of resort hotels are an ordinary result of the various other changes experienced by the tourism industry. This chapter discusses the main areas of change to this industry and the impact of those changes on resort hotel design.

Changes in tourism demand and supply, as well as political, economical, socio-cultural, organizational and time-dependent changes have worked together to motivate the physical changes made to resort hotels, as well as their overall design principles.

\subsection{Changes to tourism in Antalya}

Antalya is Turkey's most popular tourist destination. Antalya has been a very important maritime city throughout its history because of its geography and climate. Both natural and historical patterns work together to form the traditional character of the city of Antalya.

The population of Antalya began to increase in 1950s due to an increase in immigration. Soon after the urbanization, the city's economic structure became inadequate. It was 1953 when the word 'tourism' began to be used in earnest. In that same year, a law promoting the tourism industry was accepted by the Parliament. Since the 1960s, tourism in the Antalya region has been a priority for Turkey, motivated by Antalya's densely natural and historical value. In 1969, the Turkish government defined a three-kilometre band of the Aegean and Mediterranean as a dedicated tourism region. In 1973, the Ministry of Culture and Tourism had the Master Plan of Antalya prepared. The plan projected a 174,000bed capacity by the year 2000 . The number of beds exceeded the target bed number and reached 230,000 in 2000; today Antalya has a 385,000-bed capacity.

In 1980, tourism was further encouraged as a new sector, with economic and political objectives. The support given to tourism entrepreneurs by the government through the government's decisions regarding tourism planning has accelerated the demand for resort accommodations. From the 1980s on, through the support of foreign investment aimed at benefitting from this growing industry, a different process began. This process was later improved-upon through the franchise chain system.

Tourism is now the second-largest industry in Turkey, attracting a total of 28.6 million visitors per year. Today the number of tourists visiting Antalya alone has reached 9.6 million visitors per year. Antalya has attracted visitors from Germany, Russia, Austria, Sweden, the UK, Netherlands, France, Denmark, Belgium, Norway, Poland, and the Ukraine. Germany (27\%) and 
Russia (26\% - after the collapse of the Soviet Union) make up $53 \%$ of the market share in tourism [1].

Throughout this rapid acceleration in the city's tourist profile, Antalya's demographics, demands and expectations, management systems and marketing strategies have also evolved. The increasing number of chain hotels has increased Antalya's institutionalization and standardized spatial organization. Tourists expecting an inexpensive vacation and families travelling together have begun to flock to Antalya, especially after tour operators began to take a more active role in marketing and the local resorts expanded to incorporate an allinclusive accommodation system (Table 1).

Baraner [2] indicates that tourists' demands for variety and innovation will increase, be polarized, and switch from the ' $3 \mathrm{~S}$ ' (Sea, Sand, and Sun) to the ' $3 E$ ' (Education, Entertainment, and the Environment) in the coming years. He also identifies the primary long-term tourism trends as: sustainability, inexpensive but high-quality resorts, multiple destination vacations, exotic and authentic locations, unique experiences, adventure and excitement focused vacations, cultural tours and activities, recreation and sports, health and wellness, and individual tours. Finally, Baraner [2] argues that investors should focus on consumer-based sustainable tourism alternatives in order to have balanced tourism development.

\subsection{Impacts of change on resort hotel design}

Over the years, hotel designs have changed both symbolically and technically. During the course of the hotel design process, an architect's decision-making and problem-solving choices are affected by the changing demands of the tourism industry, as well as evolving styles of management, shifting economic conditions, changes to laws and codes, architectural trends and tendencies, spatial and functional necessities, and physical and technical requirements.

Today, it is apparent that the demands of the consumers who frequent resort hotels have changed, and that resort owners can no longer be content with meeting a basic need for accommodations. Consumers expect more from resort locations, such as entertainment, adventure, and extensive facilities. Shows and attractions now play a key role, and resorts aim to make the act of consuming something to enjoy (Yirtici [3]).

These days, the majority of consumers who comprise the largest portion of the market share that prefers Antalya as a vacation destination are families traveling with children. As a result, resort hotels in the area are now being designed in to meet these families' demands by adding family guestrooms and expanding activities geared towards children. It is expected that Antalya will also see an increase in the number of elderly European tourists and single female tourists, two groups who have begun to take up an increasing portion of the global market share. In both cases, such a demand shift would likely result in more health and wellness centers and more women-oriented activities at resort hotels (Yetis [4]).

Due to the substantial increase in international tourists resulting from the political changes in Europe and Russia, resort hotels have changed to meet the 
demands of tourists from various nationalities. German tourists tend to prefer vacationing in nature, and middle-aged tourists are more likely to return to locations they've already visited. Affluent British tourists tend to prefer golf resorts. Russians visiting areas for the first time are more likely to seek out unique experiences and locations as they have recently switched to a Liberal Economic system and have desire to see new places (Arabaci [5]).

After the millennium, the most important change seen in resort hotel design was a shift from the Full Board (FB) or Half Board (HB) systems to all-inclusive system. Before the all-inclusive system, resorts were designed to maximize the amount of tourist consumption. As resort hotels have switched to all-inclusive system, they have experienced a new need to control the amount of consumed free services. Rather than designing free service areas like restaurants and bars at the most desirable and attractive locations on the resort grounds, architects now focus on constructing health and wellness centers and shopping areas, both locations where consumers pay additional fees.

One of the major changes in the hotel management system is the tendency towards outsourcing certain services. Outsourcing allows resorts the opportunity to spend less space on service areas such as kitchens, laundries, night shows and activity spaces. Thus, these spaces are made more available for transformations, and are designed with new and innovative aspects in mind.

It is no longer enough for resort hotels simply to be comfortable. Furthermore, international standards such as ISO 9000 and ISO 14000 must be achieved (Kars [6]). As European consumers are increasingly seeking resorts that achieve these standards, resort hotels that aim to achieve these standards will earn more of the market share. These standards also require changes in services offered, infrastructure, materials, systems and spatial organizations.

Change in tourism and the impacts of such changes on architectural planning and design are classified and listed below (Table 1):

Table 1: Changes in tourism and the impacts of such change on resort hotel design.

\begin{tabular}{|c|c|c|}
\hline \multicolumn{2}{|r|}{ Areas of Change } & $\begin{array}{l}\text { Impacts of Change on } \\
\text { Resort Hotel Design }\end{array}$ \\
\hline 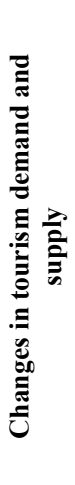 & $\begin{array}{l}\text { - Incremental increase in mass tourism } \\
\text { - Changes in tourist profile (increase in } \\
\text { variety of international tourists after the } \\
\text { political changes in Europe and Russia; } \\
\text { increasing number of families, young } \\
\text { tourists, single female tourists, and } \\
\text { elderly tourists; competing demands and } \\
\text { expectations of tourists; explicit changes } \\
\text { in tourist identity and consumer } \\
\text { behaviour, shifts from recreation to } \\
\text { entertainment) } \\
\text { - Alternative tourism activities (golf, } \\
\text { health and wellness, conventions, etc.) } \\
\text { - Changes in marketing strategies (shift to } \\
\text { an all-inclusive system) }\end{array}$ & $\begin{array}{l}\text { - Innovations toward designing 'different' } \\
\text { - Designing regardless of context; losing } \\
\text { the 'sense of place'; creating spaces that } \\
\text { can be 'everywhere but nowhere' } \\
\text { - Shift from local images to popular } \\
\text { images } \\
\text { - Increasing number of activity and } \\
\text { entertainment areas } \\
\text { - Expanded capacity to meet tourist } \\
\text { demand } \\
\text { - Improving family concepts due to } \\
\text { increasing number of families travelling } \\
\text { - Increase in variety of night shows and } \\
\text { activity spaces }\end{array}$ \\
\hline
\end{tabular}


Table 1: $\quad$ Continued.

\begin{tabular}{|c|c|c|}
\hline & Areas of Change & $\begin{array}{l}\text { Impacts of Change on } \\
\text { Resort Hotel Design }\end{array}$ \\
\hline & $\begin{array}{l}\text { - Growing capitalist economy; fast } \\
\text { production process; consumption } \\
\text { - Incremental increase in globalism; global } \\
\text { economy and competitiveness; time- } \\
\text { space compression (Urry [7]) } \\
\text { - Political changes (the disintegration of } \\
\text { the USSR; political changes in the } \\
\text { Middle East) }\end{array}$ & $\begin{array}{l}\text { - Designing new consumption places and } \\
\text { images } \\
\text { - Shortening economic life (planning on } \\
10-15 \text { year cycles) } \\
\text { - Expanded capacity to meet new tourist } \\
\text { demand } \\
\text { - Pursuit of different images to survive in } \\
\text { global competition }\end{array}$ \\
\hline 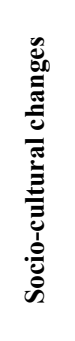 & $\begin{array}{l}\text { - Increasing tendency towards } \\
\text { individualism } \\
\text { - Changes in the tourist experience; } \\
\text { experiencing the dream; authenticity; } \\
\text { escapism; booming 'experience' } \\
\text { economy (Riewoldt [8]) } \\
\text { - Increasing amount of leisure time and } \\
\text { activities } \\
\text { - Competing demands and expectations of } \\
\text { tourists }\end{array}$ & $\begin{array}{l}\text { - Designing trendy spaces to meet popular } \\
\text { expectations } \\
\text { - Designing new consumption places and } \\
\text { images } \\
\text { - Renovations to meet new expectations } \\
\text { of boundless new activities } \\
\text { - Increase in variety of entertainment and } \\
\text { activity spaces }\end{array}$ \\
\hline 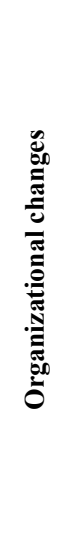 & $\begin{array}{l}\text { - Increasing tendency towards branding } \\
\text { (equilibrium in marketing, lower } \\
\text { marketing cost) } \\
\text { - Increasing number of chain hotels } \\
\text { (standardization, credibility, the power of } \\
\text { corporate identity) } \\
\text { - Outsourcing } \\
\text { - Changes in the relationship between tour } \\
\text { operators and hotel managers } \\
\text { (increasingly active role of tour operators } \\
\text { on marketing, manager's bargaining } \\
\text { power against tour operators) } \\
\text { - International Organization for Standards } \\
\text { (ISO; such as risk, quality, energy, } \\
\text { environmental management) }\end{array}$ & $\begin{array}{l}\text { - Changing functions of spaces; flexible } \\
\text { spaces (additions to the established } \\
\text { hotels, re-designing useless spaces } \\
\text { because of outsourcing) } \\
\text { - Changes in spatial organizations to meet } \\
\text { new demands (chain hotels and their } \\
\text { specific standards, tour operators' } \\
\text { demands, additional spaces and } \\
\text { activities) } \\
\text { - Expanded capacity after organizational } \\
\text { changes } \\
\text { - Renovations to meet international } \\
\text { standards } \\
\text { - Changing images to meet new corporate } \\
\text { identities, renewing corporate identities } \\
\text { and related images }\end{array}$ \\
\hline 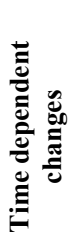 & $\begin{array}{l}\text { - Aging; maintenance } \\
\text { - Technological innovations } \\
\text { - Environmental factors; sustainability }\end{array}$ & $\begin{array}{l}\text { - Renovation of hotels } \\
\text { - Renewing of infrastructure } \\
\text { - Technological improvements (wi-fi } \\
\text { connections, pay TV, interactive TV, } \\
\text { DVDs, RFID cards, etc.) } \\
\text { - Sustainable materials; ISO 14000; } \\
\text { energy-saving systems }\end{array}$ \\
\hline
\end{tabular}




\section{Renovations in resort hotels}

For existing resort hotels, renovation is inevitable. As different groups of tourists come to frequent particular resort hotels, resort hotels must make renovations to appeal to their different tastes and needs. Globally, the standard amount of time that passes before a resort hotel should consider renovation is approximately 10 years. In Turkey, this point was reached in the late 1990s. In order to retain the market advantage of offering new, high-quality, modern resort hotels, the Turkish tourism industry turned its attention towards renovations in the 2000s (Akdag [9]).

According to Ayik [10], the most important reasons for renovation include: (1) to keep room rates high in a competitive environment, (2) to retain bargaining power while dealing with tour operators, (3) to increase market share by offering new, unique products to consumers, and (4) to compete with new and newly-renovated resort hotels. The main reasons for renovating resort hotels are discussed more fully below:

- $\quad$ Being trendy:

Renovations in resort hotels are necessary in order to keep up with recent developments in technology and design, to keep the hotel appearing fresh to encourage repeat business (Vickers [11]), and to provide the 'new', the 'popular', and the 'different' that so many tourists have come to expect. Resort hotels compete with each other to provide tourists a sense of something different. Reimer suggests that the need for the 'different' is the reason behind the industry's move towards new types of itineraries, activities, destinations, marketing strategies, and themed environments (Reimer [12]).

- Tour operators' demands:

Tour operators motivate resort hotels to renovate their facilities, and demanding that owners have new and high quality resort hotels available for their customers [5].

- Changes in the tourist's profile, demographic and types of demands:

A slight change in the profile of the target population for the resort will eventually lead to a need for major changes or renovations at the resort complex. Resort hotels must be designed and renovated to accommodate these changes to tourist profiles and demographics if they hope to meet tourist demands and survive in the market (Orhon [13]).

- $\quad$ Expanding the market with different alternatives:

Research has shown that the current demands placed upon resorts are not limited to the offered accommodations. Consumers are now seeking fun, adventure, and seemingly-unlimited activities from their resort. Resorts hotels should offer a variety of alternatives such as congress centers, golf clubs, health and wellness centers, and sports centers if they hope to attract visitors.

- Changes in marketing strategies and a shift to the all-inclusive system:

The shift from Full Board (FB) and Half Board (HB) to an all-inclusive system requires certain changes to resort hotels to increase the profitability of the facility. For instance, architects should motivate visitors to consume less of the 
free services (rooms, restaurants and bars) and more of the paid services (health and wellness centers, water sports, golf and other activities) with their designs.

- Changes in management systems and/or managers

Constant changes occur in management systems and/or managers due to the rapidly changing nature of the tourism industry. New management often requires new organizational forms, standards and images in order to further the new corporate identity.

- Technological innovations

Technological improvements such as wi-fi connections, pay TV, interactive TV, DVDs, and RFID cards are vital if a resort hopes to keep up with technological innovations and increase the comfort level of their guests.

- International standards on health, safety and quality

Today it is impossible for hotels to survive unless they meet internationally approved standards for health, safety and quality. Increasing tourist demands force managers continuously to improve upon their own internal standards. The main international standards for safety, quality and environmental management systems include ISO 9000 (Quality Management Systems), ISO 14000 (Environmental Management Systems), and HACCP (Hazard Analysis and Critical Control Points).

- Aging

Even though the renovation lifespan for a resort hotel generally is considered to be 10 years, lobbies and other public spaces should be renovated in three to five year cycles, and guestrooms are likely to need renovation every five to seven years, in order to keep the hotel fresh. Furniture, carpets, bed covers, skirts, sheets, curtains and other fabric materials should be changed every five years [13].

Renovations made to resort hotels in Antalya, Turkey will be examined in the following chapter, using as a case study twelve resort hotels that were renovated between 2001 and 2005 .

\section{A case study on the renovations of resort hotels in Antalya: 2001-2005}

Tourism in Antalya peaked in the years 1994-1995 and 1999-2000. This acceleration encouraged developers to renovate their hotels and expand their recreation facilities. In 2002, tourism research showed that $27 \%$ of hotels in Turkey began to slip from international standards [14], and 550 hotels were over 10 years old and in need of renovation. Of the 550 hotels that were built in the 1990s, 178 in Antalya needed urgent renovations due to aging and changes in tourism [15].

This research focuses on the resort hotels built between 1987 and 1997 in Antalya. Twelve resort hotels that were renovated between 2001 and 2005 were selected and surveyed, and all renovated spaces were analyzed in order to explore the level and types of changes made in the new designs. 
This research determined that the guestrooms, the main restaurant and the lobby were the primary renovation areas due to the aging these areas had suffered since 2001.

- Guestrooms: Carpets, bed covers and furniture were renovated in guestrooms due to the aging problem faced by 10 of the 12 resort hotels. Only the bathrooms were renovated at Pirates' Beach Club and Hotel in Saray Side. Seven hotels renovated their suites as well as their standard guestrooms.

- Lobby: Because the lobby is the first resort space that guests experience, it creates the initial image of the resort in guests' minds. Consequently, hotel developers give high priority to the renovation of their lobbies. The reception desk, concierge and lounge areas were renovated at seven of the surveyed resort hotels. Shopping areas were also added around the lobby of the Gloria Golf Resort.

- Restaurants: At five of the hotels, the main restaurants and their kitchens were renovated in order to achieve HACCP standards. Changes to the restaurants and bars were also required due to a general shift to an all-inclusive system designed to control the amount of food consumed.

- Leisure and Entertainment: Four hotels renovated their theaters, night shows and activity spaces; two hotels renovated their nightclubs. Swimming pools and pool bars were renovated at three of the 12 hotels; four hotels added children's pools, and three hotels added activity pools.

- Sports: Most of the surveyed hotels provide areas for sports activities such as mini-soccer, basketball, volleyball, handball, and table tennis, as well as tennis courts and water sports centers. Besides these activities, two hotels added bowling halls, one hotel added archery, one hotel added soccer, and two hotels added golf courses.

- Health and Wellness: Most of the hotels surveyed have Turkish baths, saunas, fitness centers, and indoor pools. Pirates' Beach Club renovated its sauna and Turkish bath, and added massage rooms.

Hotel developers erred on the side of caution in 2001 and focused mostly on vital renovations. However, in the subsequent years, developers have tended towards adding more activity and entertainment spaces, and expanding the services offered by the resorts.

The renovations and other changes to these 12 resort hotels between the years 2002 and 2005 were also analyzed for this research. The most important difference between the renovations in 2001 and the later renovations was the expanded variety of services and activities offered. To survive in the competitive resort environment, to meet tour operators' and tourists' demands, and to increase market share, the surveyed hotels both renovated their spaces and expanded their activities.

- Guestrooms: One of the biggest changes was the expansion of the 'family' concept. Children's spaces and activities were expanded, due to an increasing number of families visiting the hotels. In this sense, five hotels added family rooms, one hotel added junior suites, one hotel added deluxe guestrooms, and two hotels added villas. Besides these 
additions, the standard rooms were renovated at four out of the 12 surveyed hotels.

- Lobby: Three hotels renovated their lobby spaces in order to provide the resorts with updated images and a trendier look.

- Restaurants: Main restaurants and their kitchens were renovated at four hotels. Six hotels added á la carte menus, and four hotels added children's restaurants.

- Leisure and Entertainment: Five hotels renovated their theaters, night shows and activity spaces, and two hotels renovated their nightclubs. Swimming pools and pool bars were renovated at two out of the 12 surveyed hotels, three hotels added activity pools; two hotels added indoor pools; and two hotels opened new aquapark centers.

- Sports: Besides other activities, five hotels added archery, one hotel added soccer, three hotels added mini-soccer, and two hotels added squash tennis.

- Health and Wellness: Turkish baths, saunas, massage rooms and indoor pools were renovated at five hotels. Health and wellness centers were established with the new additions such as Finnish baths, bath therapy centers, steam rooms, aromatherapy rooms, areas for stone massages, solariums, and spaces for face and body care.

- Activities: Four hotels added multi-purpose meeting rooms, and four hotels renovated existing rooms of this type. The Adora Golf Hotel and the Sunrise Queen Hotel expanded their recreation facilities and established congress centers. Three hotels renovated their shopping centers, and one hotel added more shops.

- Children's Activities: Nine hotels changed their core concept to a 'family' concept. One hotel renovated its children's club, and eight hotels added new clubs. Hotel Turquoise added a small zoo in order to expand the activities offered for children.

- Technology: Six hotels implemented wi-fi systems in order to provide their guests access to the internet.

From this research, it can be concluded that the major renovations in 2001 were on guestrooms, restaurants and lobby spaces attributed to the hotels' 'aging' problem. The renovations between 2002 and 2005 were mostly focused on expanding facilities and activities (á la carte restaurants, activity pools, aquaparks, shopping centers, congress centers, nightclubs, night shows and activity spaces, sports, health and wellness centers), and improving upon the 'family' concept (adding suites, family rooms, villas, children's clubs, activities and pools).

Research performed by the Association of Mediterranean Hoteliers (AKTOB) shows that two of the primary reasons for the renovation of resort hotels are: (1) to be able to compete with new hotels, and (2) to increase bargaining power with tour operators [14].

All of the changes in the spatial organization of hotels, as well as the increase in new additions and functions, increase the difficulty of the design problem. Architects should find unique and flexible solutions emerging from this 
competitive environment, where design concerns and functional and spatial necessities are constantly changing.

\section{Conclusion}

This study examines and analyzes the motives for changes in resort hotels, and evaluates the impacts of such changes on resort hotel design. After identifying the areas most impacted by changes, criteria providing conscious and insightful approaches to design problems were determined.

Riewoldt [8] states "At the same time the economic life of hotels is getting shorter: hotel projects are now planned over amortization periods of only 10 to 15 years; there is an increasing demand for the new." Even though this concept may not seem realistic for hotels in Turkey, it is still an interesting statement as it emphasizes the rapid consumption of hotels and their overall temporariness. It can be expected that designers might envision this temporariness beforehand and reflect it in their designs, developing flexible designs that would more easily comply with the shifting of tourist consumers. Once researchers have come to this conclusion, the question becomes: "is it possible to assess ever-changing resort hotels within the framework of conventional spatial design?"

Auge [16] states, "If a place can be defined as rational, historical and concerned with identity, then a space which cannot be defined as rational, or historical, or concerned with identity will be a non-place. The hypothesis advanced here is that supermodernity produces non-places, meaning spaces which are not themselves anthropological places and which do not integrate the earlier places." Based on this identification, we can easily define resort hotels as non-places like airports and shopping malls. If this is the case, it is worth it to discuss new design principles that might be applied to resort hotels. Perhaps resort hotels should intentionally be designed as non-places, with their own design principles that differ from those of conventional places. Processes of design should be well analyzed, and all variables such as sector, investor and tourist demands should be determined prior to design. The architect's role here should be to provide a more flexible and unique design capable of meeting all the necessities of a non-place without losing the architectural quality necessary to meet tourist expectations.

The dramatic shift in the design of resort hotels indicates that resort hotels should be redefined as a new building typology. This new type, where design criteria differs from those of other building types, should not be assessed within the conventional typology of hotels. Resorts host an endless variety of functions, set up temporary experiences, and involve much more frequent changes in the types of consumption they offer. Additionally, it is not favorable to adopt a recognized architectural demeanor and, consequently, search for conventional spaces in the design of resort hotels that are planned for recreation, fun and games, activities and adventure.

Resort hotels also differ from other types of structures by virtue of their design process. This design process necessitates a strong collaboration between the investors, managers and designers in all stages including strategic planning, 
design and construction. Additionally, parallel to consumer demands, the design process continues throughout the lifetime of the building. In the design of resort hotels, an accurate analysis of the design process, which involves many variables, and precise detection of the design input, demands and expectations of tourism is very important to the success of the facility. The design problem should be handled by means of a flexible approach with an eye towards the constant changes in the types of tourist consumption.

Besides all of the differences that require a new definition of resort hotels, resort hotels should be designed with an eye towards the particular boundaries and context of the structure itself, in order to provide the all -important feeling of being 'different'. In sum, the architect is now expected to search for design quality, uniqueness and flexibility while simultaneously accommodating for the constantly shifting nature of the design input, functional and spatial requirements of the resort hotel.

\section{References}

[1] Ministry of Culture and Tourism - Antalya http://www.antalyakulturturizm.gov.tr/belge/1-63048/kultur-turizmistatistikleri.html (accessed 03/18/2012).

[2] Baraner, H., 2004. Avrupa Turizm Talebinde Gelisme Egilimleri ve Antalya, Vizyon, 202, 8-15.

[3] Yirtici, H., Tuketimin Mekansal Orgutlenmesinin Ideolojisi, Mimarlik ve Tuketim, Boyut Yayin Grubu, Istanbul, 2002. p.9-39.

[4] Yetis, M., 2005. Oral Interview. (Manager of TUI)

[5] Arabaci, H., 2005. Oral Interview. (Manager of Asteria Hotels \& Resorts)

[6] Kars, K., 2004. Antalya Turizminde 2004 Y1l Degerlendirmesi ve Gelecek Vizyonu, Antalya Ticaret ve Sanayi Odası Raporu, Antalya.

[7] Urry, J., Consuming Places, Routledge, 1995. p.22.

[8] Riewoldt, O., New Hotel Design, Watson-Guptill Publications, New York. 2002. p.11.

[9] Akdag, B.O., 2003. Simdi Tesislerimiz Bir Numara, ya Yarin!, Tourism World, 3, 10-15.

[10] Ayik, O., 2005. Oral Interview. (Director of Association of Mediterranean Hoteliers - AKTOB)

[11] Vickers, G., $21^{\text {st }}$ Century Hotel, Laurence King Publishing, London. 2005. p.8-11.

[12] Reimer, G., "Packing Dreams: Canadian Tour operators at Work", Annals of Tourism Research, vol.17, 1990. p.501-512.

[13] Orhon, O., 2005. Oral Interview (Architect, Board member Aksoy Group)

[14] Anonymous, 2002. Yaşlı Tesisler Yenileniyor, Tourism Today, 1, 90-92.

[15] Turizmde $\mathrm{Bu}$ Sabah, "Turizmciler 2001" de Kazandıklarını Yenilemeye Yatırdı", http://www.turizmdebusabah.com/haber_detay.aspx? haberNo=2939 (accessed 07/12/2002).

[16] Auge, M., Non-Places, Verso, New York, 1995. p.63. 